
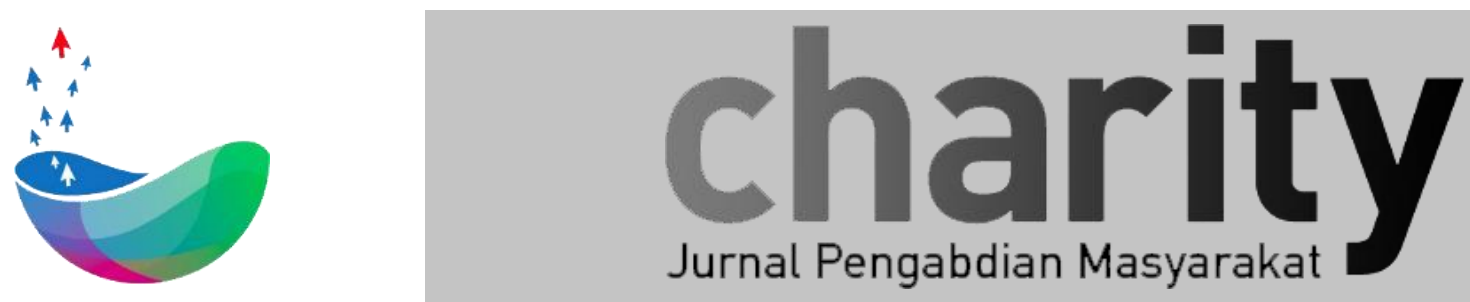

\title{
STRATEGI PENJUALAN PRODUK BERBAHAN DASAR KELAPA DI BADAN KESWADAYAAN MASYARAKAT ( BKM WONOMUKTI) PAGUYUBAN WARGA DESA MONOHARJO
}

\author{
Leni Cahyani ${ }^{1}$. Ilhamsyah ${ }^{2}$ M. Hidayatullah ${ }^{3}$ Arlin F.M. Trenggana ${ }^{4}$, Alini Gilang ${ }^{5}$
}

Program Studi Manajemen Pemasaran, Fakultas Ilmu Terepan, Universitas Telkom Program Studi Desain Komunikasi Visual, Fakultas indrustri kreatif, Universitas Telkom Program Studi Desain Komunikasi Visual, Fakultas indrustri kreatif, Universitas Telkom Program Studi Administrasi Bisnis, Fakultas komunikasi Bisnis, Universitas Telkom Program Studi Administrasi Bisnis, Fakultas komunikasi Bisnis, Universitas Telkom

lenicahyani@tass.telkomuniversity.ac.id

\section{INFO ARTIKEL}

Diterima 4 Juli 2019

Direvisi 11 Juli 2019

Disetujui 30 Agustus 2019

Tersedia Online 6 Juli 2020

\begin{abstract}
ABSTRAK
Pangandaran merupakan daerah yang potensi terbesarnya sumber daya alam apalagi dari sektor parawisata yang sudah lama ada sehingga produktivitas masyarakat sekitarnya berpengaruh kepada pengunjung. Peranan dari daerah terkait dengan adanya pengembangan Usaha kecil yang dikelola oleh BKM Wonomukti, salah satunya adalah gula semut yang merupakan salah satu usaha yang dijalani oleh masyarakat sekitar Pangandaran. Desa Wonoharjo adalah salah satu desa yang memiliki potensi untuk dikembangkan melalui berbagai strategi penjualan. Permasalahan yang menjadi prioritas dari mitra usaha kecil saat ini pada petani gula semut meliputi yaitu pengolahan gula semut, kreativitas dan kemasan gula semut sendiri. Selain itu permasalahan pasar belum mampu memanfaatkan peluang yang ada, kurangnya akses, serta belum adanya Kemitraan Usaha. Hasil yang dicapai pada pengabdian masyarakat di desa Wonoharjo sangat besar motivasinya dengan pendampingan yang langsung terjun kepada masyarakat pengrajin gula semut, batok kelapa dan ayaman lidi yang berpotensi tinggi dalam meningkatkan UMKM di Pangandaran. Adanya inovasi kemasan, daya saing jual dan pemasaran melalui web salah satu yang bisa dicapai oleh akademisi dan UMKM gula semut.
\end{abstract}

: Strategi penjualan, Pengembangan pemasaran dan inovasi kemasan, WEB

\section{Keyword :}

\author{
Korespondensi : \\ Direktorat Penelitian dan Pengabdian Masyarakat, Universitas Telkom \\ Jl. Telekomunikasi No. 1, Terusan Buah Batu, Bandung, 40257 \\ Indonesia. \\ E-mail: charity@telkomuniversity.ac.id \\ ORCID ID: - \\ Penulis Pertama: Leni Cahyani \\ https://doi.org/ 10.25124/charity.v2i2.2105
}


Paper_reg_number 2105 (C) The Authors. Published by Directorate of Research and Community Service, Telkom University.

This is an open access article under the CC BY-NC 4.0 license (https://creativecommons.org/licenses/by-nc/4.0/)

\section{PENDAHULUAN}

Hasil warisan dari orang tua dahulu yaitu mengelola berbahan dasar dari Kelapa yang merupakan mata pencaharian penduduk di Desa Wonoharjo. Dekatnya posisi daerah dengan pesisir pantai yang melimpah ruah pohon kelapa dijadikan sebagai usaha sampingan penduduk sekitar pantai. Masyarakat memproduksi gula kelapa menjadi gula merah cetak, dengan proses sederhana, dan penjualan lebih banyak dijual ke pabrik-pabrik sebagai bahan baku kecap.

Setelah adanya Sertifikat produksi Pangan Industri Rumah Tangga (PIRT) pada tahun 2017, menjadi pijakan awal bagi produk gula semut asal Kecamatan/Kabupaten Pangandaran untuk memperluas pemasaran, sehingga pada saat ini produk gula yang dihasilkan sudah dapat menembus pasar Jepang dan Eropa. (Sumber : kadinpangandaran, 2018). Bahan baku gula semut adalah nira yang berasal dari pohon kelapa dan pohon aren. Keduanya memiliki perbedaan dalam hal warna, aroma, rasa, dan kadar kotorannya. Nira aren jika dibandingkan dengan nira kelapa, berasa lebih manis, lebih jernih, dan lebih segar, dan lebih rendah jumlah padatan yang terlarutnya.

Hasil kunjungan lapangan ke lokasi mitra diketahui pula bahwa Lembaga Keswadayaan Masyarakat (BKM/LKM) Wonomukti yang merupakan himpunan masyarakat, telah melaksanakan tugasnya sebagai wadah menampung dan mengelola aspirasi dari masyarakat. Baik itu pelaksanaan PJM awal sampai sekarang. Kegiatan BKM didukung aparat desa dan masyarakat Desa sekitar. BKM merupakan alternatif pilihan bagi warga masyarakat, sebagai lembaga yang menjadi motor penggerak dalam penanggulangan kemiskinan seperti yang dibutuhkan oleh masyarakat.

Seiring meluasnya pasar dan meningkatnya keuntungan, makin banyak pula perajin gula yang bergabung dalam produksi gula semut. Saat ini anggota BKM di Kecamatan Pangandaran mencapai 140 orang, dari awalnya hanya 54 orang. Kapasitas produksi pun sudah mencapai 8-10 ton per bulan, dimana rata-rata 3 ton di antaranya diperuntukkan bagi pasar Jepang dan Eropa, meski proses penjualannya masih melalui perantara eksportir gula di Purwokerto, Jawa Tengah.(Sumber: kadinpangandaran.2018). Walaupun pada kenyataannya lingkungan sekitar termasuk pemerintah daerah mempunyai harapan nantinya dapat menjual gula semut oleh sendiri tanpa pihak siapapun, dengan meningkatan sumber daya manusia yang produktif dan peningkatan perekonomian yang lebih baik lagi dengan nilai jual yang tinggi.

\section{MASALAH}

Berdasarkan survey dari permasalahan, maka tim dengan kedua mitra memutuskan (justifikasi) maka permasalahan prioritas yang akan dicarikan solusinya, sebagai berikut: Permasalahan Proses hingga penjualan produk yang sudah diProduksi oleh mitra

1. Terbatasnya pengembangan produk hasil BKM di pangandaran

2. Permasalahan Organisasi dan Manajemen, masih sederhana, belum memiliki Visi dan Misi yang jelas, belum menerapkan dan menjalankan organisasi dan manajemen usaha yang benar.

3. Permasalahan Produk : keterbatasan daya kreativitas, Belum memiliki ciri khas produk sendiri,(produk unggulan), belum memiliki merk produk pada mitra.

4. Belum Memiliki Rencana usaha (Business Plan) secara tertulis, yang meliputi Penentuan: Aspek pasar dan pemasaran yang meliputi perencanaan produk, harga, wilayah(daerah), Aspek produksi seperti perencanaan bahan baku, jenis dan kuantitasnya, perencanaan peralatan dan perlengkapan proses produksi, serta aspek keuangan baik untuk modal kerja maupun untuk investasi termasuk Laporan Keuangan. 
5. Belum memiliki link penjualan produk gula semut dari kelapa.

6. Permasalahan pasar sasaran, belum mampu memanfaatkan peluang pasar yang ada, Akses Terhadap Klien/Calon Pelanggan serta belum adanya Kemitraan Usaha

7. Belum Mengembangkan produk hasil karya mastarakat dengan pemberdayaan daerah wisata

\section{METODE KEGIATAN}

3.1 Metode Kegiatan Pengabdian

Berdasarkan Solusi Dan Target Luaran dari rencana pelaksanaan program PKM pada kedua mitra yang telah ditetapkan, maka tim menetapkan metode pendekatan sebagai berikut :

A. Metode Pelatihan Metode pelatihan, ditujukan untuk mentrasfer Ilmu pengetahuan dan teknologi (Ipteks) dalam mengatasi permasalahan melalui peningkatkan wawasan, pemahaman bagi mitra. Yang mana pelaksanaan pelatihan direncanakan dilaksanakan dalam satu ruangan di Balai desa atau kecamatan. Adapun metode pendekatan ini ditetapkan oleh tim untuk mengatasi permasalahan, dan solusi mencapai target luaran yang telah ditetapkan yaitu Pengembagan produk, jenis, motif, kombinas, serta ciri khas produk (produk unggulan) dan Merk Produk pada mitra .

B. Metode Bimbingan Teknis dan Pendampingan Metode Pendekatan ini, ditujukan untuk mentrasfer ipteks, agar kedua mitra mampu mempraktekan hasil dari pendekatan pelatihan dengan Bimbingan Teknis dan Pendampingan dari pakarnya (tim), dimana metode pendekatan ini di laksanakan langsung di lapangan(masing - masing tempat Mitra). Pakar/Tim bertindak secara aplikatif untuk mengarahkan, membimbing proses dan tahapan, memberi contoh, kepada Mitra dalam mengatasi permasalah dan mencapai target dan luaran dari Peningkatan kapasitas organisi dan manajemen usaha, Pengembangan daya krativitas, Pengembangan Produk dan Penyusunan Rencana Bisnis (Business Plan) pada mitra.

C. Metode Pendekatan Fasilitasi dan Media Metode pendekatan ini, ditujukan untuk mempermudah, meringankan, memperlancar, menghubungkan, membuatkan (mendesain), mendapatkan, dan memiliki sesuatu yang dibutuhkan oleh mitra. Pendekatan Fasilitasi dan mediasi bagi mitra ini digunakan dalam mengatasi permasalah dan mencapai target dan luaran sebagai berikut :

1. Fasilitasi dan mediasi fasilitasi akses terhadap klien/calon pelanggan dan mediasi kemitraan usaha

2. Membuatkan (mendesain) media promosi Website/Blog

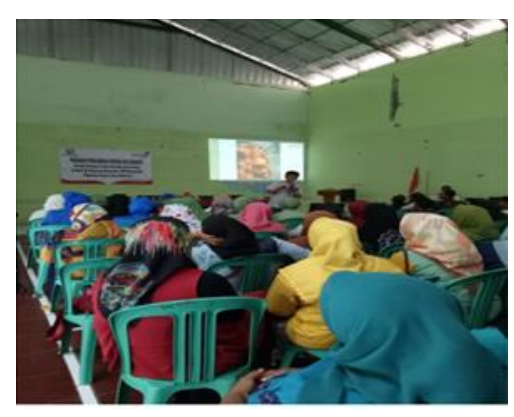

Gambar 1: Kegiatan di Pelatihan

Sumber : Dokumentasi pribadi 


\subsection{Teknik Pengumpulan Data}

Teknik Pengambilan data berupa pertanyaan dari survey, wawancara dan observasi.

\subsection{Teknik Analisis Data}

Deskriptif kuantitatif adalah teknik analisis data yang dilakukan yang bertujuan untuk mendapatkan gambaran karakteristik penduduk dan kondisi perekonomian masyarakat.

\subsection{Lokasi, Waktu, dan Durasi Kegiatan}

Kegiatan akan dilaksanakan di balai pertemuan desa Wonoharjo kabupaten Pangandaran, Jawa Barat.

\section{ANALISA HASIL KEGIATAN}

Luaran dari pengabdian masyakat yang akan kami laksanakan antara lain: Jasa Pelatihan/Penyuluhan Tentang Produk, branding, pemasaran digital dan HAKI yang diharapkan peserta selain dapat pengetahuannya juga dapat menambah wawasan tentang bagaimana meningkatkan value produk dan memasukkan unsur kearifan budaya lokal sehingga menjadi produk unggulan yang memiliki daya saing. Membuat brand yang kuat diingat oleh pasar baik dalam bentuk, warna, gambar, makna dll yang menjadi identitas kuat para UKM. Menggunakan pemasaran digital secara efektif dan optimal melalui website yang telah kami bantu. Mengajukan HAKI untuk produk yang mereka miliki, agar tidak terjadi pengakuan produk mereka oleh orang lain.

\subsection{Kegiatan}

Rekomendasi untuk kegiatan pengabdian masyarakat selanjutnya adalah dibangunnya kesadaran masyarakat akan manfaat dari program yang telah diberikan dan adanya penyesuaian dengan kebiasaan masyarakat. Selain itu diperlukan adanya komunikasi yang intens kepada masyarakat dan evaluasi yang terstruktur.

Usaha gula semut kelapa atau aren tergolong sebagai pertanian subsisten atau agribisnis yang paling primitif, yang sering dijual atau ditukar untuk memenuhi keperluan sehari-hari. Proses pengolahan gula yakni dengan peralatan masak sederhana dengan menggunakan kayu bakar. Permasalahan adalah modal usaha dimana dana yang besar ada pada pengadaan kayu bakar dan tenaga kerja. Bahan baku nira diperoleh dari hasil penyadapan kebun kelapa dan tumbuhan aren yang ada di lereng, lembah, dan pinggiran sungai. Namun jika kegiatan menyadap nira, memasak gula hingga memasarkan produk dilakukan oleh tenaga kerja keluarga ( $<4$ orang), maka pengeluaran untuk ongkos tenaga kerja sebenarnya identik dengan biaya hidup keluarga. 


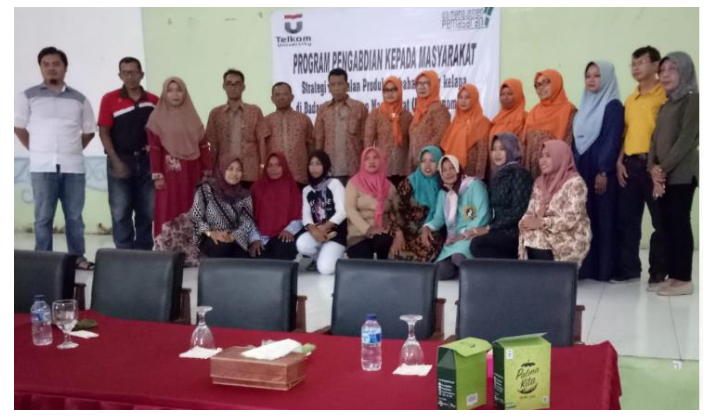

Gambar 2: Peserta Pelatihan

Sumber : Dokumentasi pribadi

Produk Palmakita merupakan produk gula semut yang diproduksi oleh BKM Sidomukti, pangandaran. Secara kemasan, gula semut tersebut pada awalnya dikemas melalui kemasan plastik dan diberikan kertas label sebagai identitas produk. Seiring dengan berjalannya usaha, palmakita berencana untuk menyasar pasar ritel sebagai jalur distribusi produk. Dengan landasan perubahan jalur dstribusi tersebut, maka diperlukanlah proses redesign kemasan produk palmakita agar bisa bersaing dengan produk lainnya.

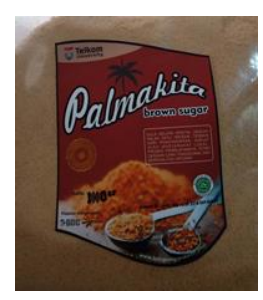

Gambar 3: kemasan awal produk palmakita Sumber : Dokumentasi pribadi

Berdasarkan paparan pada paragraf sebelumnya, tim dosen dari Universitas Telkom melalui program pengabdian kepada masyarakat memberikan pengetahuan kepada para masyarakat yang tergabung dalam kelompok BKM Sidomukti di kawasan Pangandaran mengenai peningkatan kualitas produk. Dimana, salah satu materi tersebut mengenai pentingnya kemasan dalam peningkatan mutu suatu produk. Pada program pengabdian kepada masyarakat tersebut, tim dosen juga membuat proto type kemasan produk palmakita yang telah di redesign.

\section{Proses perancangan redesign kemasan produk Palmakita. a.Penentuan material kemasan}

Mengingat adanya kebutuhan dari produk palmakita yang akan meningkatkan jalur distibusinya kearah ritel, maka langkah yang pertama dilakukan dalam proses perancangan ialah mencari beberapa reverensi visual dari produk yang sudah dijual di pasar ritel. Dalam hal ini, fokus yang ditujukan ialah mencari material yang baik dalam melindungi produk sekaligus mampu memberikan nilai estetis ketika produk di tampilkan pada suatu rak.

Mengingat banyaknya material bahan yang digunakan sebagai kemasan, maka diputuskan material kertas yang akan digunakan sebagai kemasan dari gula semut Palmakita. Pemilihan kertas sebagai material dikarenakan kemudahannya untuk memberikan tampilan visual berupa image maupun elemen grafis lainnya dan banyaknya akses keberbagai percetakan kertas yang sudah banyak tersebar di berbagai kota. 


\section{b.Analisis kompetitor sebagai reverensi visual}

Setelah menentukan material kemasan, maka langkah selanjutnya ialah menganalisis beberapa kemasan kompetitor produk gula semut sehingga dapat ditentukan key visual baik warna maupun image yang telah digunakan serta sudah difahami oleh masyarakat umum

Berdasarkan pada key visual yang telah disebutkan pada pembahasan sebelumya, maka proses desain diawali dengan pembuatan sketsa dengan tema tumbuhan pesisir. Proses sketsa diawali dengan sketsa manual dan dilanjutkan dengan proses digitalisasi melalui software grafis berbasis vector. Key visual yang telah terbentuk secara digital selanjutnya akan dirangkai sebagai background kemasan yang berperan sebagai tekstur untuk meningkatkan aspek emosi pada kemasan tersebut. Mengingat material yang digunakan ialah kertas, maka pembuatan pola kemasan merupakan hal yang dilakukan. Dimana pola kemasan ini selanjutnya akan dilakukan proses pelipatan sehingga menghasilkan bentuk tiga dimensi dari bentukan box persegi.

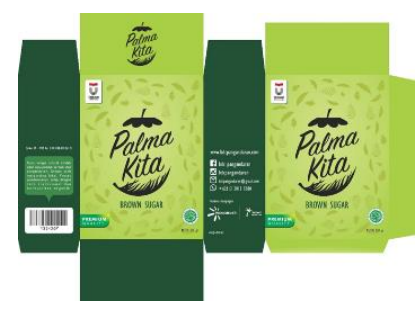

Gambar 4: Pola kemasan palmakita untuk alternative pertama Sumber: dokumentasi pribadi

Secara warna, kemasan palmakita yang dirancang mengedepankan warna hijau sebagai warna dominannya untuk menggambarkan sifat alami dan nilai sehat yang dimiliki oleh produk tersebut. Selain dari itu, penggunaan huruf sanserif ditujukan untuk membuat visualisasi desain yang terkesan lebih modern. Sedangkan informasi mengenai produk seperti halal, produksi, dan lain-lain, disebar di beberapa area pada kemasan, baik pada bagian depan, samping kanan dan kiri, maupun pada bagian belakang.

\section{DAFTAR PUSTAKA}

Kadin Pangangdaran (2018) ............ http://www.kadinpangandaran.or.id/2018.

\section{LAMPIRAN KEGIATAN}
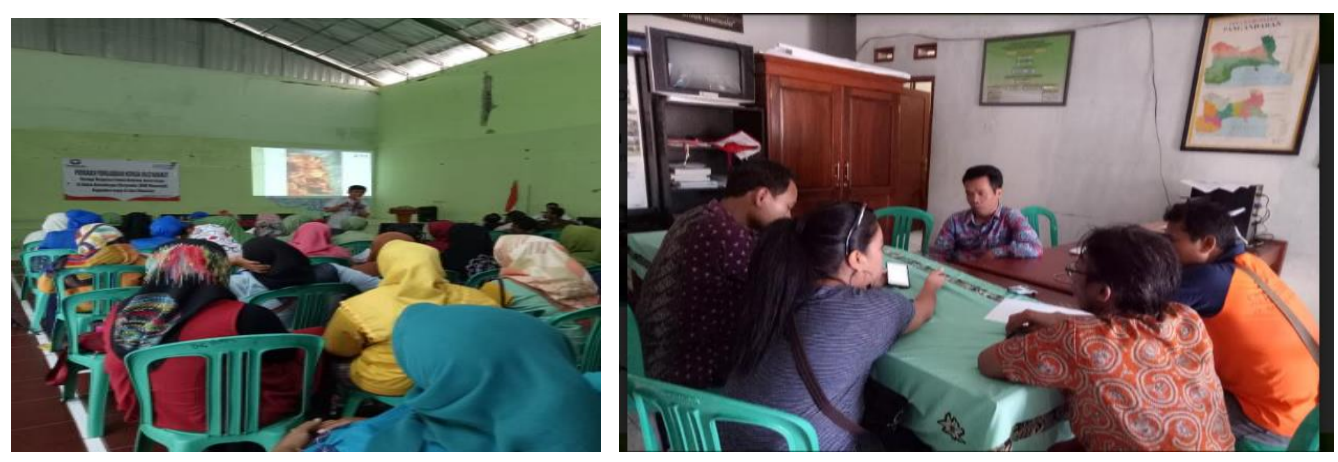


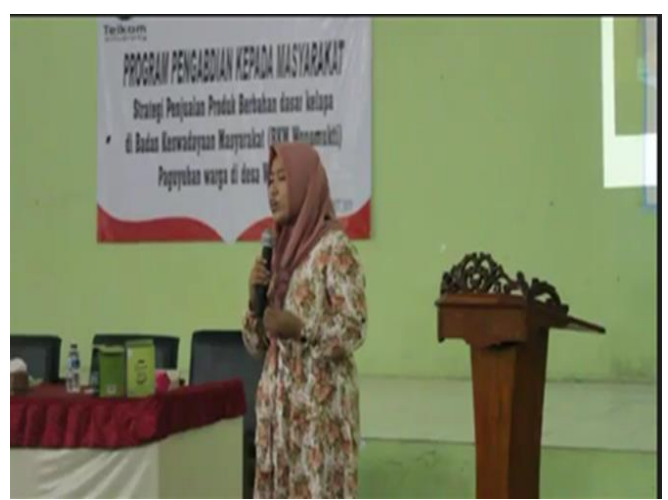

